\title{
Study on the Development of Sports Culture under the Background of "Belt and Road"
}

\author{
Yang Feng \\ Xi'an International University, Shaanxi Xi'an, 710077, China
}

Keywords: Belt and Road, sports culture, development

\begin{abstract}
The "Belt and Road" is "China's great initiative and public products of international cooperation". The aim is to promote the common development of all countries in the region, strengthen exchanges and mutual learning among civilizations, and create "Politics Community, Responsibility Community and Destiny Community of Mutual Trust, Economic Integration and Cultural Inclusion”. The essence of national renaissance is the renaissance of Chinese culture and the rise of sports culture in China in the process of building national physique, shaping national image and displaying national soft power.
\end{abstract}

\section{Introduction}

At present, China's sports are also facing the rise from a sports power to a sports power which facing the hegemony of western culture and the strong position of sports, the international communication of sports culture should deal with the idea of "one belt and one road" culture in advance, and speed up the strategy with the help of the "one belt and one road" strategy whose own pace of international communication, it will achieve the great revival of China's sports culture historical mission. At the same time, cultural exchanges and cooperation along the "one belt and one road" will serve as a cultural exchange for traditional sports culture. It has created a good atmosphere, the increasingly, the close economic, trade and tourism exchanges have become a national tradition. It has laid a solid foundation for the development of education culture, and laid a solid foundation for the existing excellent national traditional sports literature. Practice provides valuable experience. The unique value of international spread of sports culture in the construction of "Take One Road". Taking sports culture as a point of contact, it can be achieved through the dual-line promotion of the government and the people. Mutual understanding and respect among different cultures along the line to enhance has trusted among countries in the region. With the help of "one belt and one road" strategy, we can enhance the international communication of sports culture in China. To strengthen the cultural influence and international discourse gains power of the countries in the region. Sports is the universal language of the world. It has transcended nationalities, religions and cultures and become a national language. The vanguard of communication and cooperation, the obstacles and resistance of international communication are relatively small, and sports events. "Integrating the common effects of population flow, information exchange and cultural dissemination" has become the world's top priority. Important ties of international exchanges, such as the Olympic Games, NBA and other sports events, have become 
important in the world. Boundary media events have strongly promoted cultural exchanges and cooperation among countries.

2. The opportunities and challenges facing China's sports culture development under the strategy of "one belt and one road".

\subsection{Opportunities for the construction of sports culture in China}

The development of sports culture is conducive to the promotion of national cultural competitiveness and future social development. From the former "hard power" competition to "soft power" competition, in fact, it is between cultures. China has always been famous for its long history, ancient civilization and comprehensive strength. We are among the best in the world, but we can't label it as a civilized and powerful country. Our Chinese nation's culture is in the international arena. It has not yet occupied a very important position. Sports has always been an important medium of culture. One of the intermediaries is also the emerging life industry with the greatest growth potential nowadays. "Soft Power" acompetition today, we must implement the latest sports development policy, implement the whole exhibition which must be supported by cultural identity, cultural self-confidence and cultural self-consciousness to bring Chinese culture into full play multiple values. The "one belt and one way" strategy is a breakthrough in the international spread of China's sports culture. Current west .By virtue of its powerful economic, military, cultural and religious forces, Fang State has firmly grasped the language. The international discourse power of cultural communication, represented by the Olympic Movement lies in the western sports. As a result of the strong position, the space pressure of sports survival and development of other nationalities has increased. It will be a long process for sports culture to achieve international communication successfully, the implementation of the road strategy is an excellent breakthrough. First, the strategy of "one belt and one road". The direction and way of international dissemination of sports culture in China are clearly defined. The direction of dissemination can revolve around land. The "Upper Belt" and the "Sea Road" are carried out simultaneously. Second, the strategy of "one belt and one road" involves the state. There are many different cultures in different countries. When conducting sports culture dissemination, we should first "grasp international dissemination". "One belt and one road" provides historical opportunities for the construction of sports culture in China. It has broad and profound connotation and plays a leading role in politics, economy and culture. The function of leading or adjusting. Nowadays, the strategy of "one belt and one road" is put forward to revive the civilization of silk road. It is conducive to forming an all-round new pattern of East-West mutual aid and building a regional interest community and Community and the realization of complementary advantages and mutual benefit and win-win situation of countries along the line. On the Construction of Sports Culture

On the other hand, it opens the main artery between China and the countries around the Silk Road, which is beneficial to the co-construction. The flagship project of educational culture construction. However, as the world's political economy enters the key of transformation and adjustment.During this period, China's strength in all aspects will inevitably not be suppressed by developed countries and other issues. The covet of developing countries blocked the road of sports cultural exchange and construction. "One belt and one road" strategy.The principles of consultation, co-construction and sharing, the concept of interconnection and mutual benefit has advocated.The sense of community of identity and destiny will push regional cooperation to a new level and height. We will strengthen the role of existing multilateral cooperation mechanisms such as SCO and APEC to promote sports culture. Construction provides organizational paths. Under this concept, China can not only push forward to the western region on its own initiative. Facing the world, the construction of sports culture will make the countries along the way benefit from each other first. 
Learning from and drawing lessons from advanced sports management, school-running experience and ideas will also change our experience. Historically, sports and cultural exchanges and construction along the Silk Road in Central Asia have been slow. The foundation of the international competitiveness of sports. Ethnic Sports Resources with Special Geographical Location and Intensity, national customs and religious cultures are different, showing regional subjectivity and wide distribution. Construct, thus is forming a unique national traditional sports culture. But there are still some people. Ethnic resources need to be further excavated and sorted out.The continuous field visits are needed to get close to all ethnic groups.

Observing and collecting more resources of traditional ethnic sports in settlements to enrich our national traditions.Sports cultural resources, so that more national traditional sports are protected and developed.Cultural system is more sound and cultural protection is more scientific and rational. The domestic challenges facing the strategy of "one belt and one road" are mainly reflected in the cross section at the national level. The lack of coordination in the door has led to a local government's understanding of the strategy of "one belt and one road" However, although China's society as a whole is in an orderly way, there are still some places and areas. But there is disorder in the field. Trans regional and cross departmental national "one belt and one way" strategic alliance.The division of labor of the regulatory agencies has not yet been clearly defined, the level of institutionalized construction needs to be improved, the details of design and details. Problems such as inadequate management lead to a lack of comparative strategic positioning and path at the national level. A high degree of consensus leads to a loss of strategic direction and neglect of process focus. Fundamental goals, or problems, are broken down into specific, tiny molecules that are not sufficient. Giving full play to the overall effect.,construction planning is not comprehensive. The political coordination and economy are not fully taken into account. Benefits and other issues lead to the fragmentation of the use of various resources, including sports resources,but unable to give full play to the systematic effect; strategic radiation provinces positioned too much .Scattered and indiscriminately put development plans into the strategic basket of "one belt and one road" and set up everywhere. The "one belt and one road" strategy organization focuses on one sports event. Failure to fully exploit high quality.Qualitative-related talents, inability to fully mobilize the enthusiasm of local society and civil forces in a timely manner,it has failure to effectively deepen and expand the social foundation of new silk road construction leads to domestic node provinces.The step-by-step coordination can not give full play to the sustainability effect.

3. The inspiration of China's sports culture development under the background of "one belt and one road" strategy

\subsection{Construction of "leading" and "leading" sports culture communication ideas in communication concept}

The greatest change in international politics in the early 21st century is the decline of the hegemony of the United States single-tier system. With the continuous rise of China, great changes have taken place in China's world status and role."Supporting role" to "protagonist" from "periphery" to "center". "One belt and one road" reflects China's rise. The strategic demand is that we should shoulder more obligations and responsibilities in the reform of global governance. In our relations, we use the mentality of big powers to think about our strategic interests. International Dissemination of Sports Culture.We should set up an international vision and a big country's thinking, from accepting the western communication theory to establishing it in an all-round way. The theoretical system of international communication with Chinese characteristics; from conforming to western communication culture to leading.The direction of international communication; from their own dominant communication pattern to the top-level design of the 
country, with the help of the new the strategy of "one belt and one road" promotes national sports marketing.

\subsection{Regulating and sorting out sports cultural resources and perfecting its system}

Sports resources are abundant and varied, and they have strong regional and national characteristics. The development of culture has inclusiveness and inheritance. We should take the essence from the current social concept. China, standardize and organize available cultural resources. Capital using current high technology and big data.Material management mode, through many aspects of sorting out and processing, to establish a sound national traditional culture and management system, which classifies and constructs fragmentary, outdated and incomplete records of the past one by one, as complete as possible to preserve traditional culture. Effective Separation of Resource System.Without a rational and orderly collection and classification of resources, it takes a lot of time and effort, only 20.In this way, the development of national traditional sports culture is just around the corner.

\subsection{The strategy of "one belt and one road" is the breakthrough of international dissemination of sports culture.}

The strength and depth of the external communication of Chinese sports culture need to be strengthened, so we should export our sports culture? Western sports represented by Olympic Games .In a strong position, "is expanding, penetrating and spreading to every corner of the world." It has become the coordinate system of world sports development, which has squeezed the diversified development of sports culture. Therefore, the internationalization of sports culture in China will be a very long process. The "exporters" for the development of world sports need long-term and continuous efforts, and "one belt and one road". The implementation of the strategy is an excellent breakthrough. The strategy of "one belt and one road" marks China.

It has changed its identity from follower of globalization to advocate of globalization, and has made it clear that China's participation in the process of globalization has been promoted.With the key areas and directions of global governance reform, it also refers to the international dissemination of sports culture.

\subsection{Expanding communication channels and promoting international right of speech}

The international communication of sports culture needs diversified channels, and different channels have different characteristics. At present, the main ways of Taijiquan's external dissemination are official dissemination and biography of boxers.

Broadcasting, educational exchange and communication, overseas association organization and communication, etc. International communication channels are decentralized. Focus should be placed on strengthening the construction of communication channels for national associations so as to enhance international communication as a whole. Communication power can also avoid the psychological exclusion of international audiences affected by official communication. Facing the world, commercialization and branding, we should also strengthen the channels of economic communication and mass communication. At present, the mass media channel is still the way most people observe and understand the society.It is the important ways affect people's sports attitude and behavior. Attention should be paid to live television broadcasting. 


\section{Conclusion}

When we face the strong position of western sports culture and the International Communication Style of "Western Strong and Weak", the implementation of the "one belt and one way" strategy has provided excellent international communication for sports culture in China. China's sustained rise will change the distribution of world economic power, and also the world. It offers another cultural choice. Sports culture should actively connect with the culture of "one belt and one road" First, we should grasp the key areas and the level of communication in the construction of "one belt and one road". Good international audience's "basic plate" and "key plate", actively change the concept of cultural communication, breakthrough the traditional mode of thinking is to achieve breakthroughs in key points from point to area, and at the same time to establish a system of accomplishment. Its theoretical development lays the foundation, expands the channels of communication and enhances the international discourse power. On the other hand,

There are many kinds of traditional sports in our country, so we should choose the cultural symbols that can represent our country and conform to the world. Fitness sports, which is the direction of sports culture development, as a leverage project of communication, is carried out through Taijiquan and Taijiquan. Major breakthroughs in wooden ball brand competitions to promote the international dissemination of China's sports culture New pattern. Cultivating sports culture as a booster for urban integration into the "one belt and one road".

\section{Acknowledgment}

An Experimental Study on the Teaching of Taijiquan Section System Embedded in the Talent Cultivation of Medical Students

Number: 16JK2166

\section{References}

[1] Yang Weilin,Investigation and Research on the Present Situation of Sports Non-profit Organizations in Changsha City [D],Sha: Hunan Normal University, 2010

[2] Huang Yaling ,Chinese Sports Association [D] Beijing Sports University, 2003

[3] Wang Jing's, Research on Sports Promoting the External Spread of Chinese Culture[J],2012(10)

[4] Wang Huihui. Non-profit Organizations Participating in Public Service [D] Hangzhou: Zhejiang University, 2010. 